\title{
ATMOSPHERIC LEAD IN ANTARCTIC ICE DURING THE LAST CLIMATIC CYCLE
}

\author{
by \\ Claude F. Boutron* ${ }^{* *}$, Clair C. Patterson**, Claude Lorius*, V.N. Petrov*** and N.I. Barkov*** \\ *(Laboratoire de Glaciologie et Géophysique de l'Environnement, \\ B.P. 96, 38402 St Martin d'Hères Cédex, France) \\ **(Division of Geological and Planetary Sciences 170-25, \\ California Institute of Technology, Pasadena, CA 91125, U.S.A.) \\ ***(Arctic and Antarctic Research Institute, Ul. Beringa 38, 199226 Leningrad, U.S.S.R.)
}

\begin{abstract}
Concentrations of lead $(\mathrm{Pb})$ have been measured by the ultra-clean isotope dilution mass spectrometry technique in various sections of the Antarctic Dome C and Vostok deep ice cores, whose ages range from 3.85 to $155 \mathrm{ka}$ B.P., in order to assess the natural, pre-human, sources of this toxic heavy metal in the global troposphere. $\mathrm{Pb}$ concentrations were very low, as low as about $0.3 \mathrm{pg} \mathrm{Pb} / \mathrm{g}$ during the Holocene and probably during the last interglacial and part of the last ice age. On the other hand, they were quite high, up to about $40 \mathrm{pg} \mathrm{Pb} / \mathrm{g}$, during the Last Glacial Maximum and at the end of the penultimate ice age. Wind-blown dust from crustal rock and soil appears to be the main natural source of $\mathrm{Pb}$ in the global troposphere. $\mathrm{Pb}$ contribution from volcanoes is significant during periods of low $\mathrm{Pb}$ only. Contribution from the oceans is insignificant.
\end{abstract}

\section{INTRODUCTION}

For twenty years there have been great controversies about the reconstruction on a global scale of past natural tropospheric fluxes of lead $(\mathrm{Pb})$ from analysis of the well-preserved ancient ice layers deposited within the Antarctic and Greenland ice sheets. Accurate knowledge of these fluxes is vital if modern $\mathrm{Pb}$ time trends are to be judged in the proper perspective (Wolff and Peel 1985, Boutron 1986, Peel 1986).

On the basis of the pioneering polar work of Murozumi and others (1969), which was confirmed 12 years later by $\mathrm{Ng}$ and Patterson (1981), Patterson and co-workers postulated that in ancient times there was no significant tropospheric $\mathrm{Pb}$ excess over $\mathrm{Pb}$ contributed by wind-blown dust from soil and rock. As a consequence, they ascribed the enormous $\mathrm{Pb}$ excess which is now indisputably present in the global troposphere of the Northern Hemisphere to emissions from automobile exhausts and smelteries (Murozumi and others 1969, Ng and Patterson 1981, Patterson and Settle 1987[a] and [b]). On the other hand, on the basis of the polar data published by Cragin and others (1975), Herron and others (1977), Herron (unpublished) and several other authors, various other investigators postulated that enormous $\mathrm{Pb}$ excesses over $\mathrm{Pb}$ contributed by dust from soil and rock was already present in ancient times (see, for instance, Herron and others 1977, Boutron 1980, Jaworowski and others 1981). It was claimed that these excesses were caused by emissions of huge quantities of $\mathrm{Pb}$ from various other sources, such as volcanoes, vegetation, rock volatilization and the oceans. Thus the enormous present-day $\mathrm{Pb}$ excess in the global troposphere of the Northern Hemisphere was claimed to be mainly natural, not anthropogenic.

The investigation of the occurrence of $\mathrm{Pb}$ in ice deposited within the Antarctic ice cap during the last $155 \mathrm{ka}$ is a unique way of addressing this controversy. This period encompasses the Holocene, the last ice age, the last interglacial, and the last part of the penultimate ice age. It was characterized by dramatic changes in the wind-entrained rock and soil dust content of the global troposphere, as evidenced by the very large changes in Al concentrations observed in the Byrd Station, Dome C and Vostok deep Antarctic ice cores. In particular, there have been three major peaks of Al (and therefore of rock and soil dust) during the last $155 \mathrm{ka}$ (Cragin and others 1977, Legrand unpublished, De Angelis and others 1987, Legrand and others, in press). The first one occurred at the end of the penultimate ice age, about $150 \mathrm{ka}$ ago; the second one occurred during the last ice age, about $60 \mathrm{ka}$ ago; and the last one occurred at the end of the last ice age, about $20 \mathrm{ka}$ ago (Fig.1a).

These three peaks allow testing of the two tropospheric $\mathrm{Pb}$ models outlined above. According to the model of Patterson and co-workers (the global lead-pollution model), changes in $\mathrm{Pb}$ concentrations should follow closely the changes in rock and soil dust concentrations, and therefore exhibit three major peaks, about 20,60 and $150 \mathrm{ka}$ ago. According to the other model (the natural sources of lead model), $\mathrm{Pb}$ concentrations would be expected not to exhibit such dependence on rock and soil dust concentrations, because contributions of $\mathrm{Pb}$ from dust would be insignificant with respect to contributions from other natural sources, and no large $\mathrm{Pb}$ concentration peaks should be observed over the past $155 \mathrm{ka}$.

We present here a discussion of the new data on the occurrence of $\mathrm{Pb}$ in Antarctic ice during the past $155 \mathrm{ka}$ which have recently been obtained from analysis of various sections of the Dome C and Vostok deep ice cores (Boutron and Patterson 1986, Boutron and others 1987).

\section{DECONTAMINATION AND ANALYSIS OF SAMPLES Description of samples}

Fourteen sections of the $905 \mathrm{~m}$ Dome $\mathrm{C}$ ice core and six sections of the $2083 \mathrm{~m}$ Vostok ice core have been analyzed for $\mathrm{Pb}$. The Dome $\mathrm{C}$ core (Lorius and others 1979) was thermally drilled during the austral summer 1977-78 in a dry hole which had not been filled with a wall-retaining fluid; it covers the past $32 \mathrm{ka}$, back to the beginning of the Last Glacial Maximum (LGM). The Vostok core (Lorius and others 1985) was thermally drilled in 1981-82 in a hole which had been filled with a hydrocarbon fluid; it was shown to cover the last $160 \mathrm{ka}$, back to the last part of the penultimate ice age (Jouzel and others 1987).

Sections selected for $\mathrm{Pb}$ analysis, packed in double-sealed polyethylene bags, were transported in frozen state to California Institute of Technology (C.I.T.). Each section was $15-30 \mathrm{~cm}$ in length, which corresponds to about 3-10 years' accumulation. The diameter of those Vostok sections which were deeper than $1506 \mathrm{~m}$ was $9.1 \mathrm{~cm}$; for all other sections, it was about $10.5 \mathrm{~cm}$. 

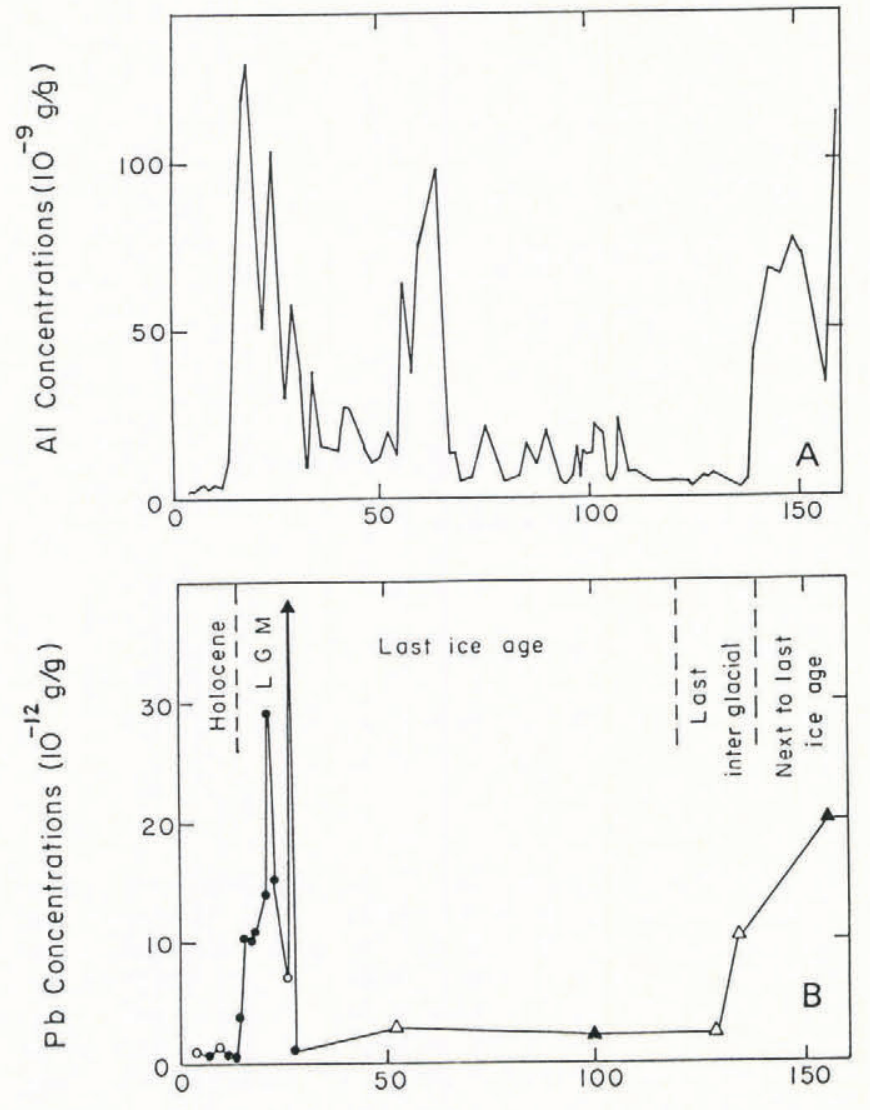

Years before present (kyr)

Fig.1. (a) Changes in aluminium concentrations in Antarctic ice during the past $155 \mathrm{ka}$, as seen in the Vostok deep ice core (from De Angelis and others 1987). (b) Changes in lead concentrations in Antarctic ice during the past $155 \mathrm{ka}$, as seen in the Dome $\mathrm{C}$ and Vostok deep ice cores (data from this study). Dots are used for data from the Dome C core sections, and triangles for data from the Vostok core sections. Open symbols indicate that the corresponding $\mathrm{Pb}$ concentration value is only an upper limit of the original concentration in the ice (see text).

Approximate limits of the successive climatic stages described by Lorius and others (1985) are shown at the top of Figure 1b.

\section{Mechanical decontamination of the core sections}

Each section was cleaned by mechanically chiseling four-six successive veneers of ice, progressing from the outside to the interior, using ultra-clean stainless-steel chisels inside a cooled double-walled nitrogen-flushed polyethylene tray in the ultra-clean C.I.T. laboratory. The inner core so obtained was $2-4 \mathrm{~cm}$ in diameter. A detailed description of the chiseling technique and of the cleaning procedures is given in Boutron and Patterson (1983 and 1986).

\section{IDMS $\mathrm{Pb}$ analysis}

For each core section, the veneer layers and the remaining inner core were analyzed separately for $\mathrm{Pb}$ by the ultra-clean isotope dilution mass spectrometry (IDMS) technique (Boutron and Patterson 1983 and 1986, Boutron and others 1987). Each analysis was corrected for the total $\mathrm{Pb}$ contamination contributed by the mechanical chiseling and chemical treatment. This overall $\mathrm{Pb}$ contamination, which was accurately determined by performing numerous separate blank measurements (Boutron and Patterson 1983 and 1986) was found to range from 30 to $60 \mathrm{pg} \mathrm{Pb}$ (in this paper, the symbol pg represents $10^{-12} \mathrm{~g}$ ). When compared with the $\mathrm{Pb}$ content of the veneer layers and of the inner cores, this $\mathrm{Pb}$ contamination correction ranged from less than $1 \%$ for outer veneer layers (in which $\mathrm{Pb}$ concentrations were very high) to up to $75 \%$ for some of the Holocene inner cores (in which $\mathrm{Pb}$ concentrations were extremely low, as low as $0.3 \mathrm{pg} \mathrm{Pb} / \mathrm{g}$ ).
The precision of the data is associated mainly with these contamination corrections. It is estimated to range from a few per cent for high $\mathrm{Pb}$ concentrations to $50 \%$ for the lowest $\mathrm{Pb}$ concentrations.

Checking the quality of each individual core section and the efficiency of the decontamination procedure

As emphasized by Wolff and Peel (1985) and Boutron (1986), it is essential to study for each individual core section the variations in $\mathrm{Pb}$ concentrations from the outside to the center as a function of radius. Only if concentrations clearly level off to a fixed value in the central parts of a section for several consecutive veneer layers can data obtained from the center of this section be accepted. Variations in $\mathrm{Pb}$ concentrations as a function of radius were studied in detail for 14 of the 20 sections analyzed in this work.

Figure 2 shows the variations in $\mathrm{Pb}$ concentrations as a function of radius in three of the Dome $\mathrm{C}$ sections and one of the Vostok sections. For the 13.9 and $18.1 \mathrm{ka}$ Dome C sections (Fig.2a and b), a clear plateau of concentrations is observed in several consecutive layers. This indicates that the mean $\mathrm{Pb}$ concentrations measured in the inner parts of these two sections (after correction for the total $\mathrm{Pb}$ contamination contributed by the mechanical chiseling and chemical treatment) do represent the original concentrations in the Antarctic ice: there was no significant contamination in the central parts of these two sections when we started to decontaminate them in the C.I.T. laboratory, and contamination which had previously affected the outside of the cores during drilling, handling and storage was not transferred to these central parts during the mechanical decontamination. On the other hand, no plateau is observed for the $38.5 \mathrm{ka}$ Dome $\mathrm{C}$ section and for the $99.7 \mathrm{ka}$ Vostok section (Fig.2c and d), which indicates that for these last two sections contamination has penetrated to the very center of the core either during drilling, transport and storage and/or during the mechanical decontamination in the laboratory. The $\mathrm{Pb}$ concentrations measured in the central parts of these last two sections must then be considered as upper limits of the original concentrations in the Antarctic ice only.

Excellent plateaus were obtained for nine of the ice sections analyzed in this work (seven Dome $\mathrm{C}$ sections and two Vostok sections). For five sections (three Dome C sections and two Vostok sections), no definite plateaus were obtained. For two Vostok sections, only the veneer next to the inner core was analyzed: for one section, $\mathrm{Pb}$ concentration in this layer was much higher than that in the inner core; for the other one, the concentrations were very similar. Finally, for four Dome $\mathrm{C}$ sections, only the inner core was analyzed. $\mathrm{Pb}$ concentrations measured in the

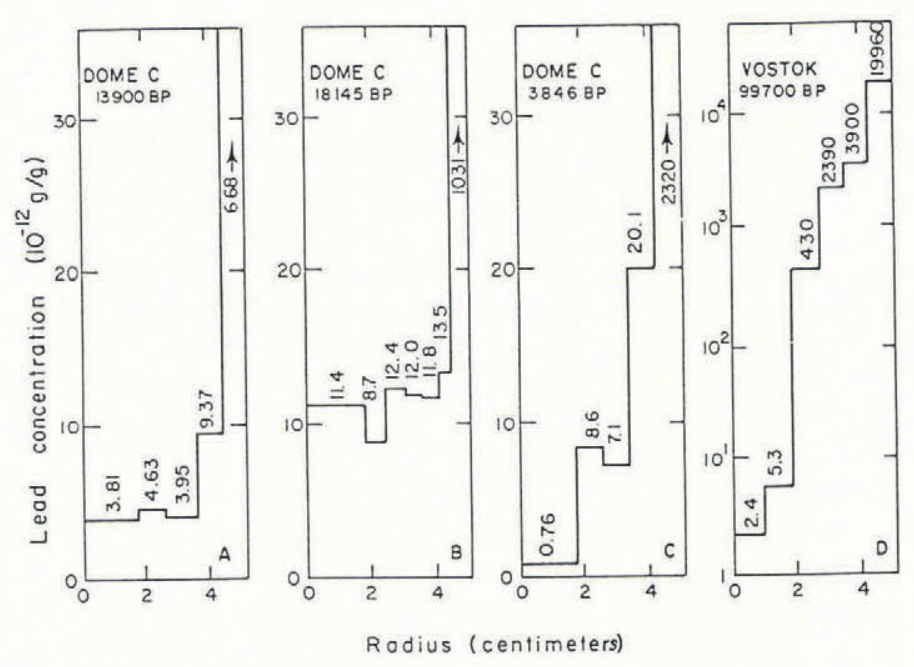

Fig.2. Variations in measured $\mathrm{Pb}$ concentrations as a function of radius in three sections of the $905 \mathrm{~m}$ Dome C Antarctic ice core (obtained by thermal drilling in a dry hole) and one section of the $2083 \mathrm{~m}$ Vostok Antarctic ice core (obtained by thermal drilling in a fluid-filled hole). 
inner cores are then thought to be the original concentrations in Antarctic ice for ten sections; for six sections, they are considered to be only upper limits. For the last four sections, we cannot determine whether the inner-core $\mathrm{Pb}$ value is the original concentration or not.

\section{RESULTS AND DISCUSSION}

Concentrations of $\mathrm{Pb}$ measured in the inner core of the Dome $\mathrm{C}$ and Vostok sections are given in Table $\mathrm{I}$.

\section{Variations in $\mathrm{Pb}$ concentrations during the last $155 \mathrm{ka}$}

Figure $1 \mathrm{~b}$ shows the variations in $\mathrm{Pb}$ concentrations in Antarctic ice as a function of the age of the ice for the $3.85-155 \mathrm{ka}$ period. The $3.85-27 \mathrm{ka}$ part of this $\mathrm{Pb}$ temporal curve is quite detailed: it demonstrates clearly that $\mathrm{Pb}$ concentrations were very low during the Holocene (from 0.32 to less than $0.94 \mathrm{pg} \mathrm{Pb} / \mathrm{g}$ ), but that they rose to very high values (up to $38 \mathrm{pg} \mathrm{Pb} / \mathrm{g}$ ) during the LGM. The pre-27 ka part of the curve, on the other hand, is only preliminary, since the Vostok data are very sparse: there are only six concentration values for the $27-155 \mathrm{ka}$ period, and three of these six values are given as upper limits only. This part of the curve, however, suggests that $\mathrm{Pb}$ concentrations were low during the last interglacial and during several periods in the last ice age, but, on the other hand, the concentrations were high $(20 \mathrm{pg} \mathrm{Pb} / \mathrm{g})$ at the end of the penultimate ice age. Obviously, new and detailed data for the 27-155 ka period will be greatly needed in the future, which emphasizes the importance of analyzing for
$\mathrm{Pb}$ various additional core sections from the Vostok deep ice core.

Changes in Antarctic precipitation rates can explain only a small fraction of the $\mathrm{Pb}$ temporal changes of two orders of magnitude shown in Figure $1 \mathrm{~b}$. Indeed, precipitation rates have probably not varied by more than a factor of 2 during the periods which have been investigated in central East Antarctica: according to Yiou and others (1985), precipitation rates during the last interglacial and during the Holocene were similar to present-day ones, whereas during the last ice age they were only about half as much.

The two periods during which we observe high $\mathrm{Pb}$ values (during the LGM and at the end of the penultimate ice age) are the periods about 20 and $150 \mathrm{ka}$ ago, during which De Angelis and others (1987) and Legrand and others (1987) observed their first and third Al peaks, described in the Introduction (see Fig.1a). On the other hand, we cannot determine whether or not $\mathrm{Pb}$ values were high during the period when they observed their second $\mathrm{Al}$ peak (about $60 \mathrm{ka}$ ago), since we have unfortunately not analyzed core sections which correspond to this second $\mathrm{Al}$ peak; these core sections will need to be analyzed in the near future.

More generally, changes in $\mathrm{Pb}$ concentrations during the past $155 \mathrm{ka}$ are found to follow closely the changes in $\mathrm{Al}$ concentrations and therefore the changes in crustal rock and soil dust concentrations. It appears, then, that these new $\mathrm{Pb}$ data are in excellent agreement with the tropospheric $\mathrm{Pb}$ model of Patterson and co-workers (the global-pollution lead model). On the other hand, they definitely disagree with the natural sources of lead model.

TABLE I. ANTARCTIC DOME C AND VOSTOK DEEP ICE CORES: MEASURED CONCENTRATIONS OF Pb IN THE INNER CORES AND EVALUATION OF RELATIVE Pb CONTRIBUTIONS FROM ROCK AND SOIL DUST, VOLCANOES AND THE OCEANS.

\begin{tabular}{|c|c|c|c|c|c|}
\hline \multirow[t]{2}{*}{$\underset{(m)}{\text { Depth }}{ }^{a}$} & \multirow{2}{*}{$\begin{array}{l}\text { Estimated b } \\
\text { age (years B.P.) }\end{array}$} & \multirow[b]{2}{*}{ Total measured } & \multicolumn{3}{|c|}{$\mathrm{Pb}$ in $\mathrm{pg} / \mathrm{g}\left(10^{-12} \mathrm{~g} / \mathrm{g}\right)$} \\
\hline & & & $\begin{array}{l}\text { Rock and soil dust } \\
\text { contribution } \mathrm{g}\end{array}$ & $\begin{array}{c}\text { Volcanic } \\
\text { contribution }\end{array}$ & $\begin{array}{c}\text { Oceanic } \\
\text { contribution }\end{array}$ \\
\hline \multicolumn{6}{|l|}{ Dome C } \\
\hline 172.8 & 3846 & $<0.76 c$ & 0.38 & 0.22 & 0.00009 \\
\hline 300.6 & 7587 & $0.47 \mathrm{~d}$ & 0.44 & 0.30 & 0.00008 \\
\hline 373.8 & 9785 & $<0.94 \mathrm{c}$ & 0.37 & 0.27 & 0.00006 \\
\hline 451.9 & 12160 & $0.43 \mathrm{~d}$ & 1.1 & 0.33 & 0.00020 \\
\hline 476.3 & 13020 & $\leqslant 0.32 \mathrm{e}$ & 0.88 & 0.33 & 0.00020 \\
\hline 500.5 & 13900 & $3.8 \mathrm{~d}$ & 2.1 & 0.35 & 0.00033 \\
\hline 527.2 & 14950 & $\leqslant 10.5 \mathrm{e}$ & 7.3 & 0.47 & 0.00040 \\
\hline 545.1 & 15705 & $10.2 \mathrm{~d}$ & 13 & 0.48 & 0.00054 \\
\hline 602.2 & 18145 & $11.4 \mathrm{~d}$ & 11 & 0.40 & 0.00045 \\
\hline 658.2 & 20590 & $\leqslant 14.0$ e & 12 & 0.56 & 0.00051 \\
\hline 670.5 & 21120 & $29.3 \mathrm{~d}$ & 6.9 & 0.47 & 0.00047 \\
\hline 704.2 & 22640 & $\leqslant 15.2 \mathrm{e}$ & 7.3 & 0.45 & 0.00050 \\
\hline 775.7 & 25860 & $<7.2 \mathrm{c}$ & 3.2 & 0.35 & 0.00038 \\
\hline 796.9 & 26830 & $1.25 \mathrm{~d}$ & 1.4 & 0.35 & 0.00035 \\
\hline \multicolumn{6}{|l|}{ Vostok } \\
\hline 499.1 & 26200 & $38 \quad \mathrm{~d}$ & 10 & 0.44 & 0.00043 \\
\hline 851.6 & 53600 & $\leqslant 3.1 \mathrm{f}$ & 3.9 & 0.54 & 0.00029 \\
\hline 1425.3 & 99700 & $\leqslant 2.4 \quad \mathrm{c}$ & 1.4 & 0.41 & 0.00017 \\
\hline 1775.4 & 129000 & $<2.6$ f & 0.5 & 0.34 & 0.00007 \\
\hline 1850.5 & 134000 & $<10.6 \quad c$ & 0.5 & 0.30 & 0.00004 \\
\hline 2026.3 & 155000 & 20 d & 14 & 0.59 & 0.00049 \\
\hline
\end{tabular}

(a) Depths are given as real depths; they are not expressed as meters of ice equivalent. (b) From Lorius and others (1979 and 1985), personal communication from J.P. Benoist and C. Ritz. (c) For this section, no plateau was obtained. (d) For this section, a good plateau was obtained. (e) For this section only the inner core was analysed. (f) For this section, only the veneer next to the inner core was analyzed. (g) Calculated from interpolated Al values (Legrand 1985, De Angelis and others 1987, Legrand and others 1987): soil dust $\mathrm{Pb}=1.7 \times 10^{-4} \mathrm{Al}$ (Patterson and Settle 1987[b]). (h) Calculated from interpolated $\mathrm{SO}_{4}$ values (Legrand 1985, Legrand and others 1987): volcanic $\mathrm{Pb}=0.32 \times 10^{-5}$ non-sea-salt $\mathrm{SO}_{4}^{4}$ (Boutron and Patterson 1986, Patterson and Settle 1987[a] and [b]). (i) Calculated from interpolated $\mathrm{Na}$ values (Legrand 1985, Legrand and others 1987): oceanic $\mathrm{Pb}=0.46 \times 10^{-8} \mathrm{Na}$ (Boutron and Patterson 1986). 
It must be noted that the $\mathrm{Pb}$ concentrations observed in Antarctic ice during the LGM and the end of the penultimate ice age are only about one-tenth of the concentrations which are found in present-day Arctic surface snow. And the low concentrations observed during the other periods are only about one-five-hundredth of those in present-day Arctic surface snow.

\section{Sources of natural $\mathrm{Pb}$ during the past $155 \mathrm{ka}$}

$\mathrm{Na}$, sulfate and $\mathrm{Al}$ have not yet been measured in the 20 core sections which were analyzed for $\mathrm{Pb}$ in this study. But values of these constituents have already been obtained for numerous other sections of the Dome $\mathrm{C}$ and Vostok cores by Legrand (1985), De Angelis and others (1987) and Legrand and others (1987), which allows us to obtain interpolated $\mathrm{Al}$, sulfate and $\mathrm{Na}$ concentration values for the core sections analyzed for $\mathrm{Pb}$.

The interpolated $\mathrm{Na}$ concentration values in our core sections varied by up to a factor of about 12 during the past $155 \mathrm{ka}$ (from about 10 up to $120 \mathrm{ng} \mathrm{Na} / \mathrm{g}$ ). After subtracting the $\mathrm{Na}$ fraction contributed by rock and soil dust (calculated from the $\mathrm{Al}$ concentrations), these $\mathrm{Na}$ values can be used to obtain estimates of the $\mathrm{Pb}$ fraction contributed by the oceans in each of our core sections, using the relation: oceanic $\mathrm{Pb}=0.46 \times 10^{-8} \mathrm{Na}$ (Boutron and Patterson 1986). This last equation combines the $\mathrm{Pb} / \mathrm{Na}$ ratio which occurred in surface sea-waters in ancient times with the $\mathrm{Pb}$ enrichment which occurred during the formation of sea spray in ancient times (Patterson and Settle 1987[b], Patterson and others 1985). As shown in Table I, the calculated oceanic contribution is always insignificant (less than one-thousandth of measured $\mathrm{Pb}$ ), which indicates that the oceans were not a significant source of natural $\mathrm{Pb}$ in the global troposphere during the last $155 \mathrm{ka}$.

Interpolated sulfate concentration values have not varied by more than a factor of about 3 during the past $155 \mathrm{ka}$ (from about 75 to $210 \mathrm{ng} \mathrm{SO} / \mathrm{g}$ ). After subtracting the $\mathrm{SO}_{4}$ fraction contributed by sea salts, these $\mathrm{SO}_{4}$ values can be used to obtain estimates of the $\mathrm{Pb}$ fraction contributed by volcanoes in each core section, by combining them with the known global fraction of volcanic sulfates (determined from the global sulfur cycle) and the known global (volcanic $\mathrm{Pb} /$ volcanic S) ratio (determined from measurements in volcanic gases; Patterson and Settle 1987[a]). The volcanic contribution calculated in Table $I$ is found to represent only a few per cent of the measured total $\mathrm{Pb}$ during the periods of high $\mathrm{Pb}$ (LGM and the end of the penultimate ice age); on the other hand, it accounts for about half of the measured total $\mathrm{Pb}$ during the periods of low $\mathrm{Pb}$ (Holocene, pre-LGM part of the last ice age, and last interglacial) (see Table I).

Interpolated Al concentration values varied by a factor of about 40 during the past $155 \mathrm{ka}$ (from about 2 to $80 \mathrm{ng} \mathrm{Al} / \mathrm{g}$ ). These $\mathrm{Al}$ values allow us to obtain estimates of the $\mathrm{Pb}$ fraction contributed by crustal rock and soil dust, from the mean $\mathrm{Pb} / \mathrm{Al}$ ratio in crustal rock and soil $\left(\mathrm{Pb} / \mathrm{Al}=1.7 \times 10^{-4}\right.$, Patterson and Settle 1987[b]). This last contribution is found to represent most of the measured total $\mathrm{Pb}$ during the periods of high $\mathrm{Pb}$, and about half of it during the periods of low $\mathrm{Pb}$, as shown in Table I.

It must be noted that for part of the core sections, the sum of the $\mathrm{Pb}$ contributions from oceans, volcanoes and rock and soil are either significantly higher or significantly lower than the total measured $\mathrm{Pb}$ concentrations (Table I). These differences are thought to be mainly due to the fact that we use interpolated $\mathrm{Na}$, sulfate and $\mathrm{Al}$ values for the calculation of these contributions. The use of interpolated values can result in errors of up to a factor of 3 , since $\mathrm{Na}$, sulfate and (in particular) $\mathrm{Al}$ exhibit within distances of decimeters or meters quite large variations along the Dome $\mathrm{C}$ and the Vostok cores.

\section{CONCLUSIONS}

During the $3.85-155 \mathrm{ka}$ period, the observed levels of $\mathrm{Pb}$ in Antarctic ice can be accounted for simply by contributions from rock and soil dust and from volcanoes. This last contribution, however, is shown to be significant only during periods of low $\mathrm{Pb}$. These new $\mathrm{Pb}$ data confirm that in ancient times there was no large excess of $\mathrm{Pb}$ over that contributed by wind-blown dust from crustal rock and soil, in accordance with the tropospheric $\mathrm{Pb}$ model of
Patterson and co-workers (the global lead-pollution model). Thus it is no longer possible to claim that the enormous $\mathrm{Pb}$ excess which is now present in the global troposphere of the Northern Hemisphere is not caused by human activity (automobile exhausts and smelteries).

\section{ACKNOWLEDGEMENTS}

This work was supported in the U.S.A. by U.S. National Science Foundation grant no DPP 840-3490, in France by the Ministère de l'Environnement, the Expéditions Polaires Françaises and the Terres Australes et Antarctiques Françaises, and in the U.S.S.R. by the Soviet Antarctic Expeditions.

\section{REFERENCES}

Boutron C F 1980 Trace metals in remote Arctic snows: natural or anthropogenic? Nature 284(5756): 575-576

Boutron C F 1986 Atmospheric toxic metals and metalloids in the snow and ice layers deposited in Greenland and Antarctica from prehistoric times to present. In Davidson C I, Nriagu J O (eds) Toxic metals in the atmosphere. Advances in environmental science and technology. New York, John Wiley: 467-505

Boutron C F, Patterson C C 1983 The occurrence of lead in Antarctic recent snow, firn deposited over the last two centuries and prehistoric ice. Geochimica et Cosmochimica Acta 47(8): 1355-1368

Boutron C F, Patterson C C 1986 Lead concentration changes in Antarctic ice during the Wisconsin/Holocene transition. Nature 323(6085): 222-225

Boutron C F, Patterson C C, Petrov V N, Barkov N I 1987 Preliminary data on changes of lead concentrations in Antarctic ice from 155,000 to 26,000 years BP. Atmospheric Environment 21(5): 1197-1202

Cragin J H, Herron M M, Langway C C Jr 1975 The chemistry of 700 years of precipitation at Dye 3, Greenland. CRREL Research Report 341

Cragin J H, Herron M M, Langway C C Jr, Klouda G 1977 Interhemispheric comparison in changes in the composition of atmospheric precipitation during the late Cenozoic era. In Dunbar $\mathrm{M} \mathrm{J}$ (ed) Polar oceans. Proceedings of the Polar Oceans Conference held at McGill University, Montreal, May, 1974. Calgary, Arctic Institute of North America: 617-631

De Angelis M, Barkov N I, Petrov V N 1987 Aerosol concentrations over the last climatic cycle $(160 \mathrm{kyr})$ from an Antarctic ice core. Nature 325(6102): 318-321

Flegal R, Patterson C C 1983 Vertical concentration profiles of lead in the central Pacific at $15^{\circ} \mathrm{N}$ and $20^{\circ} \mathrm{S}$. Earth and Planetary Science Letters 64: 19-32

Herron M M Unpublished The impact of volcanism on the chemical composition of Greenland ice sheet precipitation. (PhD thesis, State University of New York at Buffalo, 1980)

Herron M M, Langway C C Jr, Weiss $\mathrm{H} \mathrm{V}$, Cragin $\mathrm{J} \mathrm{H}$ 1977 Atmospheric trace elements and sulphate in the Greenland ice sheet. Geochimica et Cosmochimica Acta 41(7): 915-920

Jaworowski Z, Bysiek M, Kownacka L 1981 Flow of metals into the global atmosphere. Geochimica et Cosmochimica Acta 45(11): 2185-2199

Jouzel J and 6 others 1987 Vostok ice core: a continuous isotope temperature record over the last climatic cycle (160,000 years). Nature 329(6138): 403-408

Legrand M R 1985 Chimie des neiges et glaces antarctiques: un reflet de l'environnement. Grenoble, Université Scientifique et Médicale de Grenoble. Laboratoire de Glaciologie (Publication 478)

Legrand M R, Lorius C, Barkov N I, Petrov V N In press Atmospheric chemistry changes over the last climatic cycle $(150,000 \mathrm{yr})$ from Antarctic ice. Atmospheric Environment

Lorius C, Merlivat L, Jouzel J, Pourchet M 1979 A 30,000-yr climatic record from Antarctic ice. Nature 280(5724): 644-648

Lorius C and 6 others 1985 A 150,000 year climatic record from Antarctic ice. Nature 316(6029): 591-596

Murozumi M, Chow T J, Patterson C C 1969 Chemical concentrations of pollutant lead aerosols, terrestrial dusts 
and sea salts in Greenland and Antarctic snow strata. Geochimica et Cosmochimica Acta 33(10): 1247-1294

$\mathrm{Ng} \mathrm{A}$, Patterson C C 1981 Natural concentrations of lead in ancient Arctic and Antarctic ice. Geochimica et Cosmochimica Acta 45(11): 2109-2121

Patterson C C, Settle D M 1987[a] Magnitude of lead flux to the atmosphere from volcanoes. Geochimica et Cosmochimica Acta 51: 675-681

Patterson C C, Settle D M 1987[b] Eolian fluxes of industrial and natural lead to the seas at various geographic locations. Searex Newsletters 10: 19-27

Patterson C C, Settle D M, Rosman K 1985 Recycled lead in sea spray salt. Searex Newsletters 8: 8-11

Peel D A 1986 Is lead pollution of the atmosphere a global problem? Nature 323(6085): 200

Wolff E W, Peel D A 1985 The record of global pollution in polar snow and ice. Nature 313(6003): 535-540

Yiou F, Raisbeck G, Bourles D, Lorius C, Barkov N I $1985{ }^{10} \mathrm{Be}$ in ice at Vostok, Antarctica, during the last climatic cycle. Nature 316(6029): 616-617 